\title{
Evaluation of Relationships Between Ridership Demand and Transit-Oriented Development (TOD) Indicators Focused on Land Use Density, Diversity, and Accessibility: A Case Study of Existing Metro Stations in Bangkok
}

\author{
Khin Thiri Kyaw Nyunt ${ }^{1,2} \cdot$ Natachai Wongchavalidkul $^{2}$ (D)
}

Received: 24 June 2019/Revised: 28 November 2019/Accepted: 9 December 2019/Published online: 24 January 2020

(C) The Author(s) 2020

\begin{abstract}
The purpose of this work is to support the transitoriented development (TOD) in Thailand. The main research objective is to explore the relationship between ridership demand and TOD indicators, which is expected to be the first question that a developer in Thailand must be able to answer in order to direct their development plan in the right direction. Using existing Bangkok metro stations as a case study, 22 variables categorized into three groups (density, diversity, and design) were collected for an 800-m buffer area around the stations. Results of the correlation analysis between transit ridership and other variables show a significant relation with the volume of transit ridership. Bus services have a stronger influence on transit ridership than railway stations and ferries (pier). Also, the interchange stations and park-and-ride buildings are found to be the main variables that correlate directly with the transit ridership numbers. Results from the principal component analysis are used to evaluate factors of TOD characteristics for the existing Bangkok metro stations, categorized into seven factor groups.
\end{abstract}

Communicated by Marin Marinov.

Natachai Wongchavalidkul

natachai.won@mahidol.ac.th

Khin Thiri Kyaw Nyunt

khinthirikn@gmail.com

1 Department of Civil and Environmental Engineering, Faculty of Engineering, Mahidol University, 25/25 Salaya, Phuttamonthon, Nakhon Pathom 73170, Thailand

2 The Cluster of Logistics and Rail Engineering, Faculty of Engineering, Mahidol University, 25/25 Salaya, Phuttamonthon, Nakhon Pathom 73170, Thailand

Communicated by Marin Marinov.
Keywords Transit-oriented development $\cdot$ Correlation analysis - Principal component analysis - Public transportation · Ridership demand · Land use · Correlation analysis

\section{Introduction}

In recent decades, Asia-Pacific has taken the lead as the fastest-growing global region in terms of both its economy and population. The region saw overall economic growth of 5.8\% in 2017, and growth of 5.5\% is expected for 2019 [1]. In parallel with the economic growth, many cities in Asia have focused their investment in public transport infrastructure on relieving traffic congestion problems [2], and one of these cities is Bangkok.

Awakening from the recession in railway development in Thailand, building up and expanding networks of mass transit systems and public transport services is one of the working strategies of the Ministry of Transport (MoT). As a result, the approximately $100 \mathrm{~km}$ of existing Bangkok metro lines will be extended to $464 \mathrm{~km}$ by 2035 . Even though developments are progressing well as planned, further development of both infrastructure and transport services is needed for passengers continuously traveling from the trunk service lines to their destinations. Initiatives for improving transport services to promote passengers' last-mile connections include introducing autonomous vehicles [3-5] and serving bike-sharing systems [6]. In addition to operational improvements, the implementation of a transit-oriented development (TOD) strategy, which concentrates on area (infrastructure) design and development, is a means of enhancing ridership. As its concepts are related to infrastructure and land development, TOD is becoming a vital issue in improving public infrastructure in 
Thailand. In 2017, with an investment of 400 million baht, the Thai government began concentrating on the urban development platform in parallel with the development of transportation infrastructure [7].

The goal of this work is to support TOD works in Thailand. The main research objective is to explore the relationship between ridership demand and TOD indicators, which is expected to be the first question a developer in Thailand must be able to answer in order to direct their development plan in the right direction. Using existing Bangkok metro stations as a case study, this paper is organized as follows. Section 2 gives a brief overview of TOD definitions and common indicators. Section 3 presents the methodology used to explore relationships between various TOD indicators and passenger demand for the existing Bangkok metro stations. Section 4 presents the research results and discussion. Finally, Sect. 5 provides a summary of the results and conclusions drawn from the study.

\section{Transit-Oriented Development (TOD) and Its Indicators}

TOD is an urban development strategy that offers additional travel alternatives to private automobile users. It is a planning tool that integrates land use and transport systems. Typically, TOD involves creating moderate-density to highdensity areas of mixed land use within a comfortable walking distance $(800 \mathrm{~m})$ of public transportation stations [8]. Calthorpe [9] defines TOD as a mixed-use community within a comfortable walking distance of the transit stop and core commercial area that encourages people to live near a transit service and to use public transportation such as a bicycling for short trips and transit for long trips.

The general objective of TOD is to reduce private vehicle trip and motorized trips while increasing the share of public transportation and non-motorized trips. The strategy is to develop the area with the appropriate functional design, which generally includes a number of uses such as administrative, recreational, retail, and residential. TOD categorizes these functional areas into three groups, namely density, diversity, and design. Hence, the concept of TOD focuses on the built environment through changes to density, diversity, and design that can help to achieve the area development objective in reducing motorized trips. Some studies have defined this concept as "mixed-use design." Mixed-use refers to the mixed development of various urban activities including residential, retail, office, recreational, and open space, making it more convenient for residents and employees to travel by public transportation, bicycle or on foot, and can reduce the volume of motorized trips [9-12]. Several studies have explored the effects of TOD on the travel behavior of populations in their study areas. For example, Zhou et al. [13] found relationships between the volume of transit ridership and the TOD characteristics of density (population and employment), diversity (mix of land use type), design (degree of facility availability), and the number of the points of interest (POIs) in the study area. Kamruzzaman et al. [14] differentiated the commuting behavior of people living in different types of neighborhoods based on their TOD characteristics, and found that TOD actively enhanced the use of public transport and reduced the number of private vehicles in urban environments. However, a smaller effect was found in the commuter behavior of those living in traditional suburbs. Similar results were discussed by Chava et al. [15], who found that gentrification or transformation of neighborhood housing and environments based on the concept of TOD attracted more public transport users, especially those living within walkable distance of the metro stations. In addition, Ewing et al. [16] found that the vehicle trip generation rate in their comparative study areas was significantly lower at station parks with TOD than at those without TOD.

Studies have also found that the level of comfort in using public transport services plays a significant role in rider choice. Comfort levels can be related to either improved station accessibility or upgrading of services at the stations. For example, the introduction of a baggage collection system was found to increase the number of passengers using public transport [17]. Accessibility in terms of both time to the service and the time spent using the service itself also influences passenger decisions $[18,19]$. Finally, proximity is another important factor that directly affects the choice to use public transport [20, 21]. Based on the above-mentioned requirements for decisions to use public transit, TOD will help in upgrading these features and directly attract ridership or station area use.

Indicators are useful variables for measuring progress [22]. In transportation, indicators are a tool for measuring changes in the use of a system or its related environment. TOD also uses indicators as an essential tool to track TOD characteristics. These indicators mainly represent indexes that can facilitate planning decisions, and they can be both spatial and nonspatial indicators [23].

- Nonspatial indicators are related to features such as passenger load, safety in transit, frequency of service, number of route connections, and parking utilization.

- Spatial indicators include land-use diversity, mixed-use level, access path, intersection density, pedestrian catchment area, and location accessibility of the transit system.

There are many principles for indicators proposed in the related literatures. A number of authors have suggested that indicators should be comprehensive, measurable, quantifiable, clearly defined, accessible, independent, and sensitive 
to changes over time [22, 24, 25]. The selection of indicators could also be based on the essential aspects of TOD. For example, in this study, planners select transit ridership as the central aspect of their TOD. They can then define TOD indicators that are related to the transit ridership, such as land use characteristics, built environment, and design characteristics $[26,27]$. To distinguish TOD indicators, this study follows the approach by Cervero and Kockelman (1997), who proposed the 3D concept (density, diversity, and design), to evaluate and score TOD characteristics.

- Density refers to the population and employment relative to the size of the study or service area.

- Diversity refers to the form of land use and its development. This indicator helps to define the level of opportunity in initiating activities around the transit stations.

- Design focuses on the walkable and cyclable area for pedestrians, and helps to improve the accessibility of transit service and encourages people to make their trips by walking, bicycling, or transit use.
In this work, TOD indicators are selected based on the 3D concepts proposed by Cervero and Kockelman. Indicators are also selected based on the availability of data for Bangkok, Thailand. The selected indicators are listed in Table 1.

\section{Methodology}

This work focuses mainly on extracting information regarding the spatial data related to the transit station areas and evaluating the relationships within the extracted information. The research procedure involves three main steps.

- The process starts with scoping the study area and exploring the geographic boundary, as well as information that provides an overview of the transit users in the study area. Section 3.1 presents the results of this work.

Table 1 Selected TOD indicators

\begin{tabular}{|c|c|c|c|c|c|c|c|c|c|c|c|}
\hline \multirow[t]{2}{*}{ Group } & \multirow[t]{2}{*}{ Indicators } & \multirow[t]{2}{*}{ Definitions } & \multicolumn{9}{|c|}{ References } \\
\hline & & & [28] & [29] & {$[30]$} & {$[31]$} & {$[32]$} & [33] & [34] & [35] & {$[23]$} \\
\hline \multirow[t]{2}{*}{ Density } & Transit ridership & Number of passengers at the stations & & $\mathrm{x}$ & & & & & & & \\
\hline & Population density & Population per developed area & $\mathrm{x}$ & & & & & & $\mathrm{X}$ & $\mathrm{x}$ & $\mathrm{X}$ \\
\hline \multirow[t]{3}{*}{ Diversity } & Entropy & Degree of mixed land use across categories & $\mathrm{x}$ & & $\mathrm{x}$ & & & & $\mathrm{x}$ & & \\
\hline & Land use intensity & $\begin{array}{l}\text { Units of developed areas for residential, } \\
\text { commercial, office, industrial, parks, or } \\
\text { recreational use }\end{array}$ & $\mathrm{X}$ & & & & & & & & \\
\hline & Vertical mixture & $\begin{array}{l}\text { Proportion of commercial/retail parcels with more } \\
\text { than one land use category on the site }\end{array}$ & $\mathrm{x}$ & & & & & & & & \\
\hline \multirow[t]{9}{*}{ Design } & $\begin{array}{l}\text { Access to } \\
\text { municipal public } \\
\text { service facilities }\end{array}$ & $\begin{array}{l}\text { Average Euclidean distance from stations to } \\
\text { municipal public service facilities }\end{array}$ & & & & & & & & $\mathrm{X}$ & \\
\hline & $\begin{array}{l}\text { Access to } \\
\text { opportunities }\end{array}$ & $\begin{array}{l}\text { Number of jobs or accessible services within } \\
\text { walking distance of the stations }\end{array}$ & & & & & & & $\mathrm{x}$ & & \\
\hline & $\begin{array}{l}\text { Public transport } \\
\text { accessibility }\end{array}$ & $\begin{array}{l}\text { Measure of public transport network accessibility } \\
\text { in terms of walk access time and service } \\
\text { availability }\end{array}$ & & & & $\mathrm{x}$ & & & & & \\
\hline & $\begin{array}{l}\text { Expressway } \\
\text { accessibility }\end{array}$ & $\begin{array}{l}\text { Number of expressway exits/entrances in } \\
\text { proximity to the station }\end{array}$ & & & & & & & & $\mathrm{X}$ & \\
\hline & $\begin{array}{l}\text { Transit } \\
\text { interchanges }\end{array}$ & Number of accessible train routes at each station & & & & & & & $\mathrm{x}$ & & $\mathrm{x}$ \\
\hline & Public transport & $\begin{array}{l}\text { Number of public transport services offered at the } \\
\text { stations }\end{array}$ & & & & & & $\mathrm{x}$ & $\mathrm{x}$ & & \\
\hline & $\begin{array}{l}\text { Parking availability } \\
\text { for cars/four- } \\
\text { wheelers }\end{array}$ & $\begin{array}{l}\text { Number of optimum parking provided by transit } \\
\text { nodes for different modes (cars/four- } \\
\text { wheelers/cycles/bicycles) }\end{array}$ & & $\mathrm{X}$ & & & $\mathrm{x}$ & $\mathrm{x}$ & $\mathrm{x}$ & & $\mathrm{x}$ \\
\hline & $\begin{array}{l}\text { Street network } \\
\text { density }\end{array}$ & $\begin{array}{l}\text { Total length of the street network around a station } \\
\text { area representing less automobile-oriented } \\
\text { development }\end{array}$ & & & & & & $\mathrm{x}$ & & $\mathrm{x}$ & \\
\hline & Street connectivity & Number of intersections in proximity & $\mathrm{X}$ & $\mathrm{X}$ & & & & & & & \\
\hline
\end{tabular}


- The second step involves data collection and variable extraction. By referring the related research work, all data (variables) related to TOD are collected. Accessible geographic information system (GIS) data such as road networks, building use, and population density are collected, and the information is extracted into variable format. Section 3.2 presents the results of data collection and extraction, as well as a preliminary analysis of the extracted information.

- Finally, the third step of this process is the exploration of the relationship between the TOD-related variables and the existing demand for transit ridership. The two most fundamental concepts for exploring variable relationships are applied. First, a correlation analysis is applied to explore the relationship between TODrelated variables and their relationship with transit ridership demand. Secondly, there is an expectation that these collected variables will have high multicollinearity effects. Therefore, to explore the factors that are strongly related to TOD, instead of using simple multiple regression analysis, principal component analysis (PCA) is applied to explore the information factors related to TOD that could promote higher demand for transit ridership in the study area. Section 3.3 describes further details of this work.

\subsection{Study Area (Bangkok Metro Stations)}

The current Bangkok metro services comprise five service lines with 79 stations. There are now three operators with respect to the operations and services:

- Bangkok Metro Public Company Limited (BTS) operates the dark green line (BTS Sukhumvit), which is approximately $37.02 \mathrm{~km}$ long, with 22 stations. The dark green line began service for the first part in 1999, and the second part just opened in 2018. BTS also operates the light green line (BTS Silom), which is approximately $14.2 \mathrm{~km}$ long, with 13 stations. The light green line began service in 1999, the same year as the dark green line.

- Bangkok Mass Transit System Public Company Limited (BEM) operates the blue line, which is approximately $21 \mathrm{~km}$ long, with 19 stations. The blue line began service in 2014. Additionally, since 2016, BEM has operated the purple line, which is approximately $23 \mathrm{~km}$ long, with 16 stations.

- SRT Electrified Train Co., Ltd. (SRTET) operates the Airport Rail Link (ARL) service line, which is approximately $28 \mathrm{~km}$ long, with eight stations. The line connects downtown Bangkok with the Suvarnabhumi Airport and began operations in 2009.
Figure 1 shows the existing stations of the Bangkok Metro System. The historical records of metro passengers from the Traffic and Transportation Department, Bangkok Metropolitan Administration (BMA), and Office of Transport and Traffic Policy and Planning (OTP) show that in 2016, BTS had a total of 248.64 million passengers, while BEM and SRTET served a total of approximately 100.15 million and 21.13 million passengers, respectively. The data from 2012 to 2016 show that SRTET had the highest compound annual growth rate (CAGR) in passengers, at $8.32 \%$, while BTS and BEM had similar CAGR, at $4.34 \%$ r and $4.44 \%$, respectively. Figure 2 shows passenger historical records for the existing Bangkok Metro System.

We considers the TOD characteristics of 64 stations of the 79 stations. Thirteen stations from the purple line and one final station from the dark green line are excluded because their locations are outside the Bangkok Metropolitan Area. The Suvarnabhumi Airport station, the final station of the ARL, is also excluded because of its location in the international airport, making its TOD characteristics unusual compared with others in the system.

\subsection{Data Collection and Extraction}

Several types of spatial data are collected to evaluate stations' TOD characteristics (Table 2) by referring the related research work mentioned in the literatures presented in Sect. 2. The following is a brief discussion of the data set collected in this study.

First, population data and building use data are collected and used to evaluate the TOD concepts of density and diversity. The population data are available from the WorldPop Data Portal (University of Southampton, 2019), and present gridded population counts with $100-\mathrm{m}$ resolution. Figure 3 presents an example of population distribution around the metro stations in the study area. Building data are the building footprint shape data classified into three types: (1) residential, (2) commercial, industrial, and mixed use, and (3) "other" (public utility, public assistance, recreation, agriculture, parking, and abandoned areas). These data represent the land use diversity level in the vicinity of the stations. Figure 4 provides an example of building data around stations in the study area. Locations of public service facilities, landmarks, and retail services, which may attract activity in the study area, are also evaluated. Figure 5 shows the distribution of these locations in the study area.

For design and accessibility characteristics, the locations of public transport terminals and stations for other modes of travel around the metro stations help to characterize the accessibility levels. Capacities and locations of existing park-and-ride buildings and street and expressway networks are other types of data that indicate metro station accessibility. Also, the number of street intersections is an 
Fig. 1 Existing Bangkok metro stations

Fig. 2 Passenger historical records for the Bangkok Metro System (unit: person-trips). Sources: Traffic and Transportation Department, Bangkok Metropolitan Administration, and Office of Transport and Traffic Policy and Planning
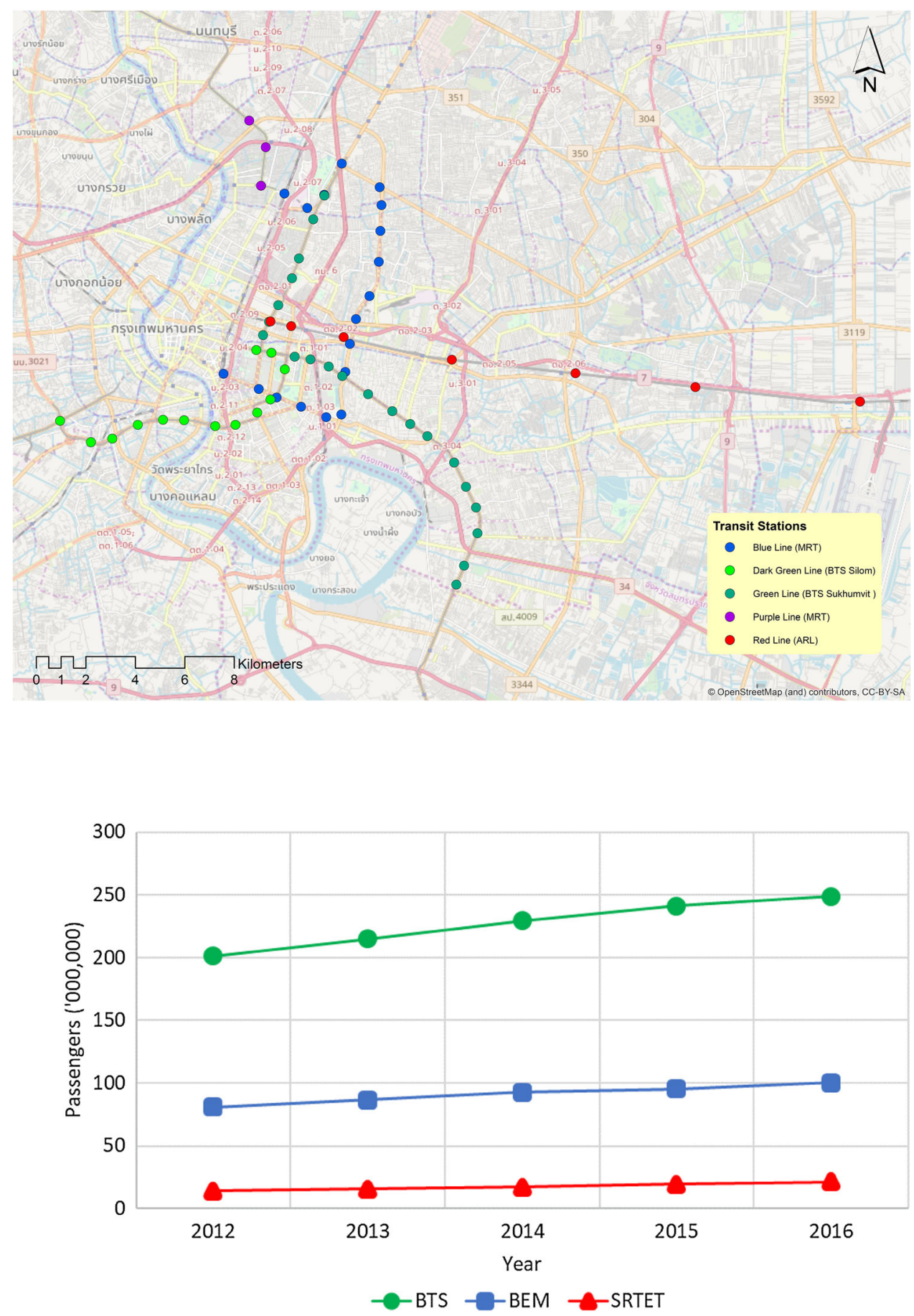

indicator of roadway congestion, which is not conducive to a walking environment. Figure 6 visualizes this set of data.

Based on the data collected as described above, 22 variables are constructed, which are categorized into three groups (density, diversity, and design) according to the $3 \mathrm{D}$ concept. Table 3 presents a list of these variables. They are then evaluated based on an 800-m buffer zone, which is the farthest comfortable walking distance for pedestrians.
Certain variables in Table 3 represent the average travel distance from the specific type of location, for example, variable $X 31$, which is the average Euclidean distance from stations to every significant municipal public service facility. In this case, a density map analysis technique is used to evaluate the Euclidean distance value for each metro station in the study area. 
Table 2 Lists of data collected

\begin{tabular}{|c|c|c|}
\hline No. & Data & Descriptions \\
\hline 1 & Population Data & Population per $100 \times 100 \mathrm{~m}$ grid area [36] \\
\hline 2 & Building data & $\begin{array}{l}\text { Building footprint data which classifies the building use type into (1) residential, (2) commercial/industrial/ } \\
\text { mixed-use, or (3) other (public utility, public assistance, recreation, agriculture, parking, and abandoned areas) }\end{array}$ \\
\hline 3 & Transit station & Locations of the transit stations \\
\hline 4 & Public service facilities & Locations of public service facilities, e.g., schools, universities, hospitals, police stations, and banks \\
\hline 5 & $\begin{array}{l}\text { Landmarks and retail } \\
\text { services }\end{array}$ & Important landmark locations (including temples) and retail services \\
\hline 6 & Public transport & Ferry, railway stations, bus lines, bus stops, and airports \\
\hline 7 & Expressway network & Expressway network including access and egress locations \\
\hline 8 & Street network & Street network including intersections, start points, and end points of the road network \\
\hline 9 & Park-and-ride & Size of the available parking spaces \\
\hline
\end{tabular}

Fig. 3 Population distribution in the study area

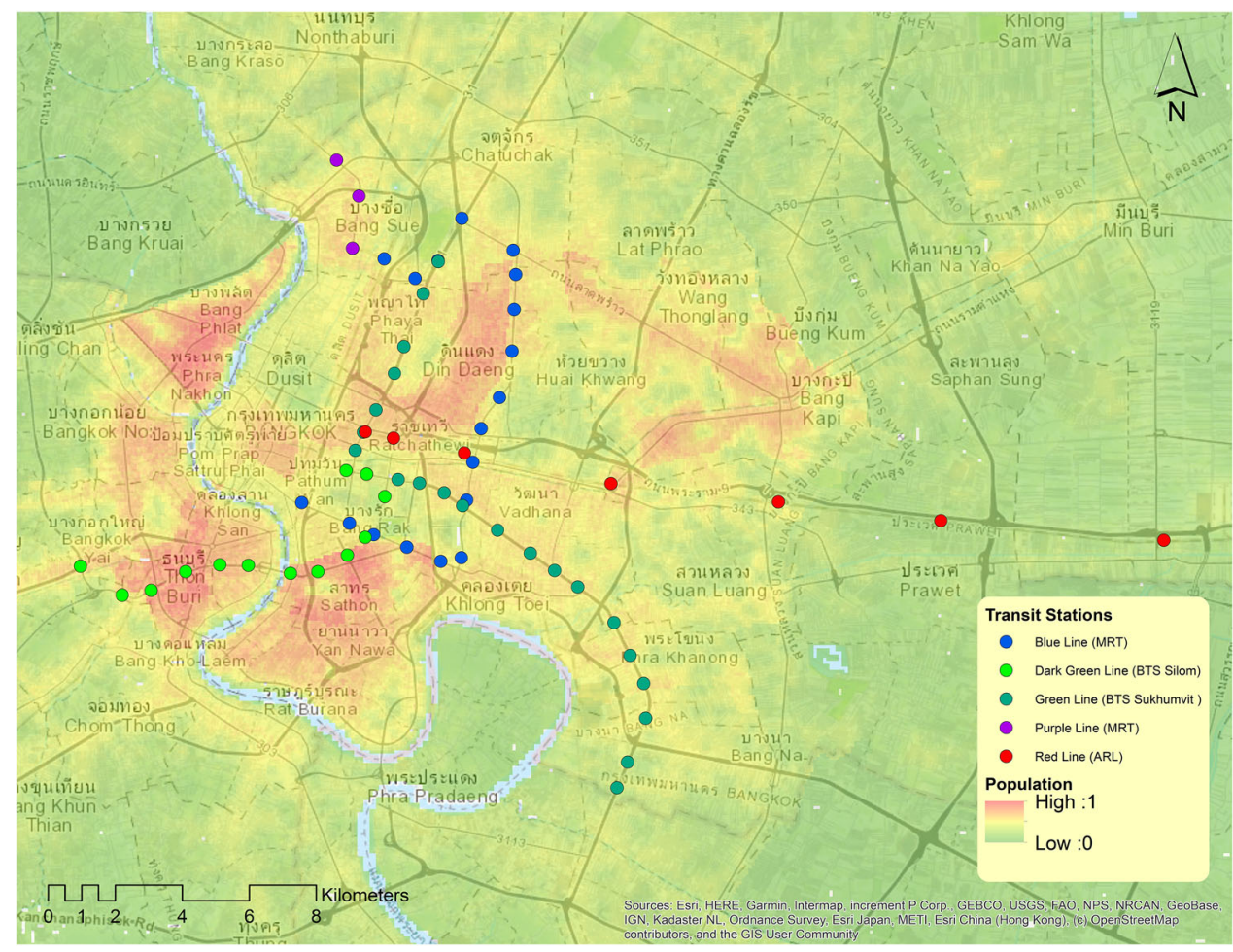

The density map analysis used in this study relies on the concept of kernel density estimation (KDE). KDE estimates the distributed value within the analysis area boundary based on the quantities of the studied points $[37,38]$. The KDE map calculates the density surface by drawing a circular neighborhood around each sample point and then applies a math function that goes from 1 at the center point to 0 at the boundary. Figure 7 presents an example of the density map estimation based on distances to significant municipal public service facilities (variable $X 31)$.

\subsection{Correlation Analysis and Exploration of Variables}

Two main analysis objectives are considered here. The first is correlation analysis, which is used to evaluate the relationship across variables. The correlation coefficient helps to measure the level of association between variables. Cohen [39] defined correlation coefficient values as follows: 0.5 or higher $=$ high correlation, $0.3=$ moderate correlation, and $0.1=$ low correlation. Statistical significance is then found when the probability value associated with the correlation is less than 0.05 . 
Fig. 4 Example of building data around stations in the study area

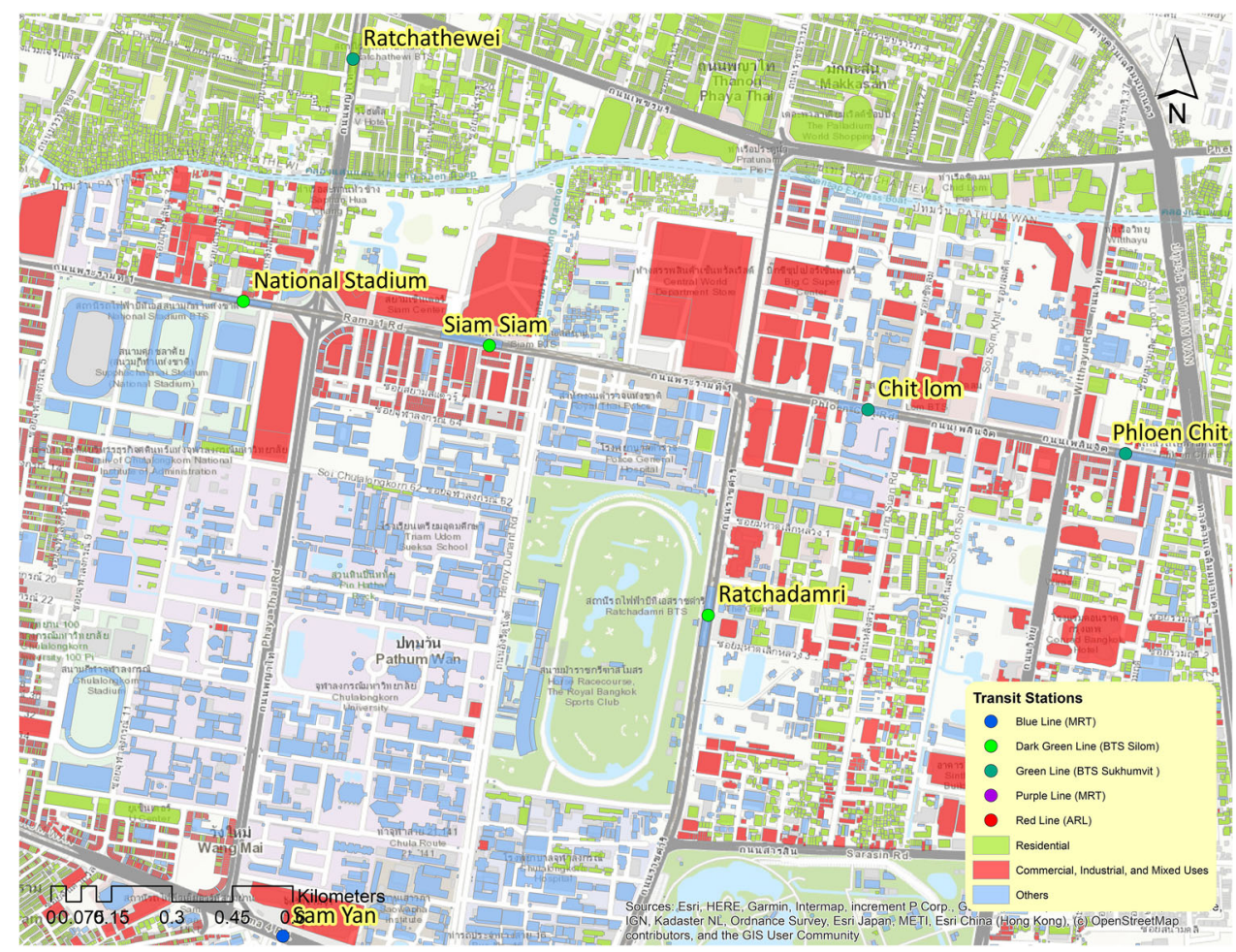

Fig. 5 Distribution of public services and landmark locations in the study area

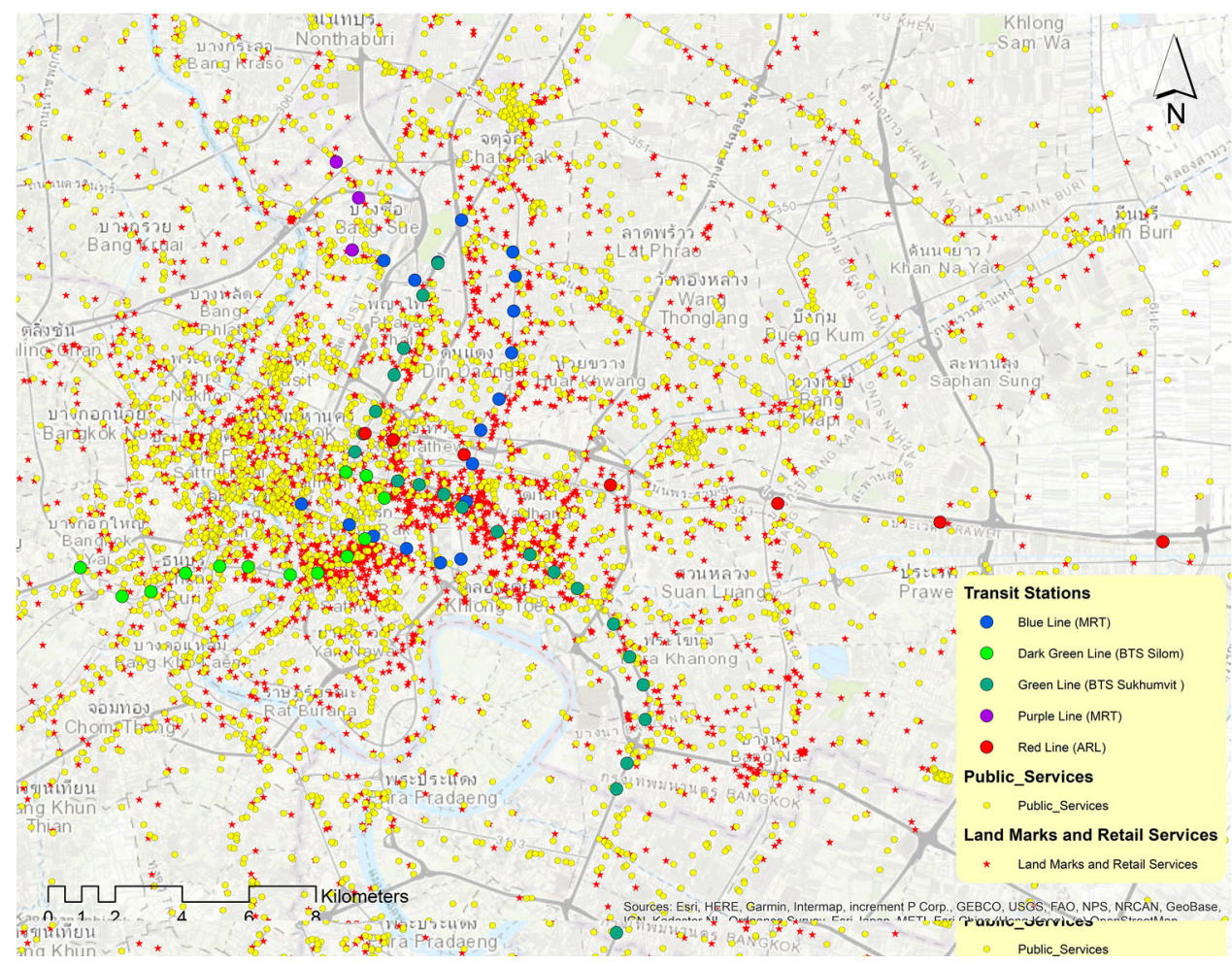

The second type of analysis used is principal component analysis (PCA), which assumes that in the collection of observed variables, there is some interrelationship between variables or a set of underlying variables called factors. In brief, PCA is used to generate new variables which are linear composites of the original variables. However, unlike the original variables, the new variables are intercorrelated. The maximum number of variables formed by the PCA is equal to the number of original variables. For example, if PCA is used to construct components based on 
Fig. 6 Public transport, parkand-ride, and road network in the study area

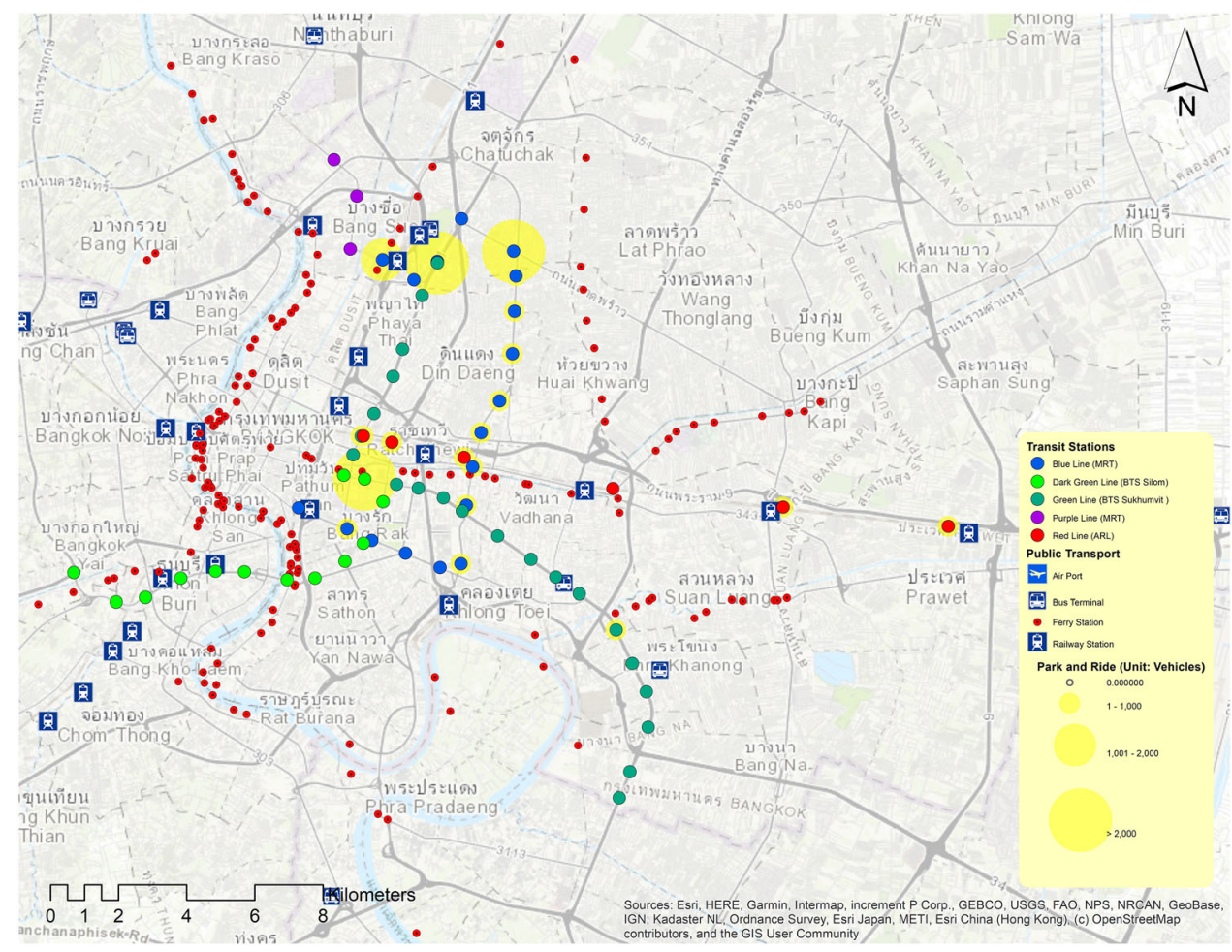

$p$ variables, the results of $p$ linear combinations could be as follows:

$$
\begin{aligned}
& \mathrm{PC} 1=w_{11} x_{1}+w_{12} x_{2}+\cdots+w_{1 i} x_{i} \\
& \mathrm{PC} 2=w_{21} x_{1}+w_{22} x_{2}+\cdots+w_{2 i} x_{i} \ldots(1) \\
& \mathrm{PCp}=w_{p 1} x_{1}+w_{p 2} x_{2}+\cdots+w_{p i} x_{i}
\end{aligned}
$$

where $\mathrm{PC} 1, \mathrm{PC} 2, \ldots, \mathrm{PC} p$ are the $p$ principal components, $w_{\mathrm{pi}}$ is the weight of the $i^{\text {th }}$ variable for the $p^{\text {th }}$ principal component, and $x_{\mathrm{i}}$ represents the observed variables. According to Sharma [40], the weights $w_{\mathrm{ij}}$ are estimated so that:

1. The first component PC1 accounts for the maximum variance in the data, while the second component PC2 accounts for the maximum variance in the data that were not considered for the first principal component, and so on.

2. $\sum_{i=1}^{p} \sum_{j} w_{p i}^{2}=1$, where $i=1,2, \ldots, p$.

3. $\sum_{i=1}^{p} \sum_{j} w_{p i}=0$, where $i \neq j$.

Details regarding how to obtain the weight in the prior equation can be found in Sharma [40].

\section{Results and Discussion}

\subsection{Overview of the Station Area Characteristics}

Table 4 presents the general descriptive statistics for selected variables in the study area, providing a general view of the variables. Important observations from the results in Table 4 are described in the following.

The number of passengers differs from station to station. The minimum volume is 964 passengers per day, while the maximum is more than 66,715 passengers per day. The area around the metro station also ranges from the lowest population density (1995 population $/ \mathrm{km}^{2}$ ) to the highest $\left(19,814\right.$ population $\left./ \mathrm{km}^{2}\right)$. The residential area comprises all metro stations. The station with the lowest density in the residential area has approximately $420000 \mathrm{~m}^{2}$ of residential floor area units.

Additionally, from variable $X 24$, on average, most station areas have a mixture of commercial, industrial, and mixed use greater than $50 \%(0.52)$ relative to the residential area. The highest portion of the commercial, industrial, and mixed use relative to the residential area is at a score of 2.59. Most stations are at a distance of less than $1 \mathrm{~km}$ from municipal public service facilities, landmarks, and retail services. The average distance from the metro stations to these locations is less than $300 \mathrm{~m}$.

Access to public transport facilities is found to vary from station to station. The station with the worst public transport accessibility is at an average Euclidean distance 
Table 3 List of selected variables

\begin{tabular}{|c|c|c|c|c|}
\hline Group & Indicator & Variable & Definition & Unit \\
\hline \multirow[t]{4}{*}{ Density } & Transit ridership & $Y$ & Number of passengers at the stations & Passengers/day \\
\hline & Population density & $X 11$ & Population per 800 -m buffer area (square meters) & $\begin{array}{l}\text { Population/ } \\
\mathrm{km}^{2}\end{array}$ \\
\hline & Population density (residential area) & $X 12$ & Population per size of residential area & Population $/ \mathrm{m}^{2}$ \\
\hline & $\begin{array}{l}\text { Population density (commercial } \\
\text { area) }\end{array}$ & $X 13$ & Population per size of commercial area & Population $/ \mathrm{m}^{2}$ \\
\hline \multirow[t]{5}{*}{ Diversity } & Residential area & $X 21$ & Residential areas (floor area units) & $\mathrm{m}^{2}$ \\
\hline & $\begin{array}{l}\text { Commercial, industrial, and mixed- } \\
\text { use area }\end{array}$ & $X 22$ & $\begin{array}{l}\text { Commercial, industrial, and mixed-use parcel areas (floor area } \\
\text { units) }\end{array}$ & $\mathrm{m}^{2}$ \\
\hline & Other activities area & $X 23$ & $\begin{array}{l}\text { Public utility, public assistance, recreation, agriculture, parking, } \\
\text { and abandoned areas (floor area units) }\end{array}$ & $\mathrm{m}^{2}$ \\
\hline & $\begin{array}{l}\text { Proportion of commercial area } \\
\text { relative to residential area }\end{array}$ & $X 24$ & Proportion of commercial area relative to residential area & - \\
\hline & $\begin{array}{l}\text { Proportion of other activity area } \\
\text { relative to residential area }\end{array}$ & $X 25$ & Proportion of other activity area relative to residential area & - \\
\hline \multirow[t]{13}{*}{ Design } & $\begin{array}{l}\text { Distance to municipal public service } \\
\text { facilities }\end{array}$ & $X 31$ & $\begin{array}{l}\text { Average Euclidean distance from stations to every significant } \\
\text { municipal public service facilities }\end{array}$ & $\mathrm{m}$ \\
\hline & $\begin{array}{l}\text { Access to landmarks and retail } \\
\text { services }\end{array}$ & $X 32$ & $\begin{array}{l}\text { Average Euclidean distance from stations to landmark and retail } \\
\text { services }\end{array}$ & $\mathrm{m}$ \\
\hline & Public transport accessibility & $X 33$ & $\begin{array}{l}\text { Average Euclidean distance from stations to other public } \\
\text { transport stations }\end{array}$ & $\mathrm{m}$ \\
\hline & Expressway accessibility & $X 34$ & Number of expressway exits/entrances within proximity & Spots \\
\hline & Interchange stations & $X 35$ & Whether the stations considered are interchange stations & $\mathrm{m}$ \\
\hline & Number of ferry services & $X 36$ & Number of ferry services in proximity to the metro stations & Ferries \\
\hline & Number of bus lines & $X 37$ & Number of bus service lines that pass through the metro stations & Lines \\
\hline & Number of bus stops & $X 38$ & Number of bus stops in proximity to the metro stations & Stops \\
\hline & Number of railway stations & $X 39$ & Number of railway stations in proximity to the metro stations & Stations \\
\hline & Park-and-ride building & $X 310$ & Size of the available parking spaces & Cars \\
\hline & Street network & $X 311$ & Total length of the street network & $\mathrm{m}$ \\
\hline & Street connectivity & $X 312$ & Number of intersections within proximity & Intersections \\
\hline & Network connectivity (cul-de-sac) & $X 313$ & Number of dead-end locations within a study area & $\begin{array}{l}\text { Start and end } \\
\text { points }\end{array}$ \\
\hline
\end{tabular}

of more than $2 \mathrm{~km}$, while the station with the best accessibility is at an average distance of only $70 \mathrm{~m}$. Also, all metro stations in the study area have at least four bus stops located within the 800-m walking distance, and at least five bus service lines pass through the metro station in the study area. Further, several stations are now provided with parkand-ride services. The largest park-and-ride service can accommodate up to 5000 parked cars. A high number of intersections is also found in the vicinity of the Metropolitan Rapid Transit (MRT) station in the study area. The station with the lowest number of intersections within its 800-m proximity still has more than 190 intersection points, while the station with the highest number has more than 1633. This volume points to the busy car traffic environment in the study area, and there are some conflicts with the pedestrian environment.

\subsection{TOD Characteristics that Influence Transit Ridership Value}

The correlation analysis between transit ridership $(Y)$ and other variables $(X \mathrm{ij})$ shows that only six variables have a significant relationship with transit ridership. These significantly correlated variables are population density (population/residential area; $X 12,-0.352$ ), interchange stations $(X 35,0.496)$, number of bus lines $(X 37,0.31)$, number of bus stops $(X 38,0.285)$, number of railway stations $(X 39,-0.271)$, and park-and-ride buildings $(X 310$, $0.623)$.

Hence, these results indicate that only density and design variables influence ridership volume for the Bangkok metro stations. In the density variable $X 12$, the proportion of population per residential floor area 
Fig. 7 An example of the density map estimation based on distances to significant municipal public service facilities (variable $X 31$ )

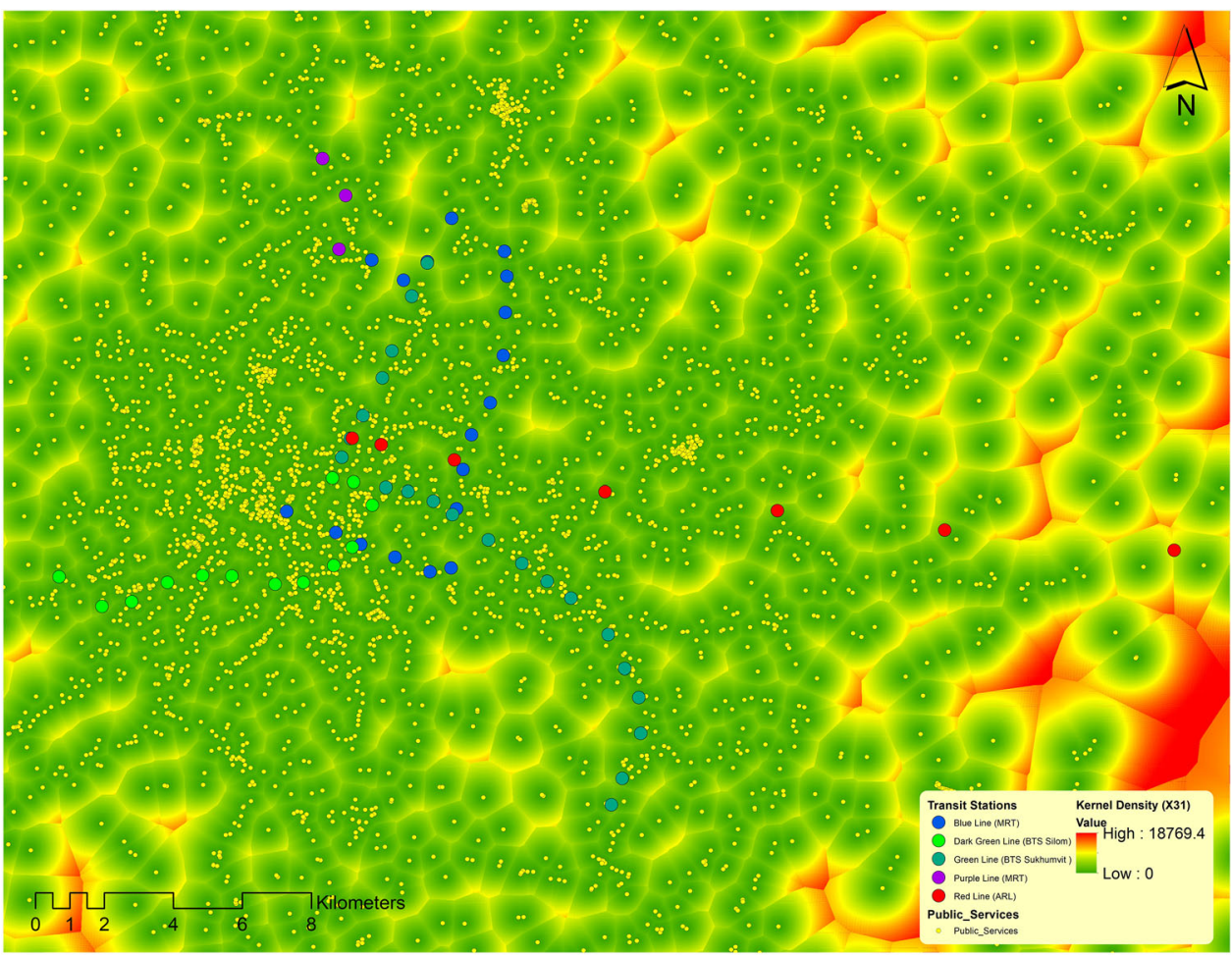

correlates negatively with transit ridership volume. This result is further evidence that the populations in high-rise buildings tend to use metro stations more than those in single houses or low-rises.

For the design of intermodal transportation, the results show that ferry $(X 36)$ is not significantly correlated with transit ridership number, while the connection of railway stations (X39) and the metro line correlates negatively with transit ridership volume at the metro stations. In contrast to ferry and railway, bus service lines (X37) and the number of bus stops $(X 38)$ are significantly correlated with the transit ridership value. Hence, based on these results, the intermodal transport improvements within the TOD in areas around the MRT stations should concentrate on the connectivity of the bus services and the MRT. These correlation results provide evidence that the chance that ferry and railway passenger travel to MRT services is interchangeable is smaller than that for passengers who take buses. Finally, the interchange station $(X 35)$ and park-andride building $(X 310)$ are strongly correlated with the transit ridership number, which is the general expectation of these variables.

\subsection{Factors of TOD Characteristics for the Bangkok Metro Stations (Principal Component Analysis)}

The results of the correlation matrix (Fig. 8) show that most items have some correlation with one another, ranging from $r=-0.484$ (for $X 312$ to $X 31$ ) to $r=0.884$ (for $X 24$ to $X 22$ ). Because of the relatively high correlation among these variables, they are interesting for use in evaluating the underlying interrelationships and help to explore the significant factors of TOD characteristics for the Bangkok metro stations.

The results of the scree plot for the PCA show that the maximum component number has an eigenvalue greater than 1 , and that the elbow point of the graph is seven components (Fig. 9). Table 5 presents results from the PCA pattern matrix. The italicized cells are the significant variables for each considered factor. The results for each component can be summarized as follows.

- Component 1 is concentrated on the design of connecting the residential area to the bus stops and roadway networks. Its main variables are population density $(X 11)$, residential area $(X 21)$, number of bus stops $(X 38)$, street network $(X 311)$, street connectivity $(X 312)$, and network connectivity (X313).

- Component 2 is concentrated on the diversity of the area including commercial, industrial, and mixed-use area $(X 22)$, other activities area (X23), proportion of commercial area relative to residential area $(X 24)$, and proportion of other activity area relative to residential area $(X 25)$.

- Component 3 includes significant variables of the residential area, which is the high-rise $(X 12)$ and also its connectivity with the railway stations $(X 39)$. 
Table 4 Descriptive statistics

\begin{tabular}{|c|c|c|c|c|c|c|c|c|}
\hline Variable & Descriptions & Unit & Mean & SD & Minimum & Maximum & Q1 & Q3 \\
\hline Y & Transit ridership & Passengers/day & 17,331 & 14,334 & 964 & 66,715 & 7829 & 21,301 \\
\hline $\mathrm{X} 11$ & Population density & $\begin{array}{l}\text { Population/ } \\
\mathrm{km}^{2}\end{array}$ & 8561 & 3745 & 1995 & 19,814 & 6213 & 10,398 \\
\hline $\mathrm{X} 12$ & Population density (residential area) & Population $/ \mathrm{m}^{2}$ & 0.01 & 0.00 & 0.01 & 0.03 & 0.01 & 0.02 \\
\hline $\mathrm{X} 13$ & Population density (commercial area) & Population $/ \mathrm{m}^{2}$ & 0.14 & 0.52 & 0.00 & 3.69 & 0.01 & 0.08 \\
\hline $\mathrm{X} 21$ & Residential area & $\mathrm{m}^{2}$ & 1.46 & 0.51 & 0.42 & 2.98 & 1.06 & 1.75 \\
\hline $\mathrm{X} 22$ & $\begin{array}{l}\text { Commercial, industrial, and mixed-use } \\
\text { area }\end{array}$ & $\mathrm{m}^{2}$ & 0.72 & 0.80 & 0.00 & 3.26 & 0.16 & 1.14 \\
\hline $\mathrm{X} 23$ & Other activities area & $\mathrm{m}^{2}$ & 0.14 & 0.12 & 0.00 & 0.59 & 0.06 & 0.21 \\
\hline $\mathrm{X} 24$ & $\begin{array}{l}\text { Proportion of commercial area relative to } \\
\text { residential area }\end{array}$ & - & 0.52 & 0.60 & 0.00 & 2.59 & 0.14 & 0.68 \\
\hline $\mathrm{X} 25$ & $\begin{array}{l}\text { Proportion of other activity area relative to } \\
\text { residential area }\end{array}$ & - & 0.12 & 0.13 & 0.00 & 0.56 & 0.04 & 0.14 \\
\hline $\mathrm{X} 31$ & $\begin{array}{l}\text { Distance to municipal public service } \\
\text { facilities }\end{array}$ & $\mathrm{m}$ & 215.32 & 171.92 & 22.36 & 934.77 & 90.13 & 323.88 \\
\hline $\mathrm{X} 32$ & Access to landmarks and retail services & $\mathrm{m}$ & 233.54 & 186.51 & 10.00 & 992.02 & 101.47 & 300.27 \\
\hline $\mathrm{X} 33$ & Public transport accessibility & $\mathrm{m}$ & 980.67 & 598.81 & 78.10 & 2369.35 & 505.49 & 1374.89 \\
\hline $\mathrm{X} 34$ & Expressway accessibility & Spots & 1.30 & 2.12 & 0.00 & 8.00 & 0.00 & 2.00 \\
\hline $\mathrm{X} 35$ & Interchange stations & $\mathrm{m}$ & 1.22 & 0.42 & 1.00 & 2.00 & 1.00 & 1.00 \\
\hline $\mathrm{X} 36$ & Number of ferry services & Ferries & 0.77 & 1.69 & 0.00 & 9.00 & 0.00 & 1.00 \\
\hline X37 & Number of bus lines & Lines & 28 & 15 & 5 & 66 & 15 & 35 \\
\hline $\mathrm{X} 38$ & Number of bus stops & Stops & 19 & 7 & 4 & 34 & 13 & 23 \\
\hline X39 & Number of railway stations & Stations & 0.14 & 0.35 & 0.00 & 1.00 & 0.00 & 0.00 \\
\hline X310 & Park-and-ride buildings & Cars & 294.06 & 958.59 & 0.00 & 5000.00 & 0.00 & 50.00 \\
\hline X311 & Street network & $\mathrm{m}$ & $37,504.93$ & 7104.60 & $21,752.13$ & $53,862.24$ & $32,493.44$ & $41,322.78$ \\
\hline $\mathrm{X} 312$ & Street connectivity & Intersections & 754 & 264 & 198 & 1633 & 579 & 917 \\
\hline X313 & Network connectivity (cul-de-sac) & $\begin{array}{l}\text { Start and end } \\
\text { points }\end{array}$ & 103 & 43 & 24 & 205 & 76 & 124 \\
\hline
\end{tabular}

See Table 2 for variable descriptions and units

- Component 4 includes significant variables of interchange stations (X35), park-and-ride building (X310), number of ferry services $(X 36)$, number of bus lines (X38), and number of bus stops $(X 39)$.

- Component 5 includes significant variables of population density $(X 11)$, which are related to the residential building floor area (X21) and ferry connectivity (X36).

- Component 6 includes significant variables of expressway accessibility (X34) and the bus line (X37).

- Component 7 includes significant variables of population density (population/commercial) (X13), the distance to municipal public service facilities $(X 31)$, and access to landmarks and retail services $(X 32)$ (Table 6).

\section{Summary and Conclusion}

The relationship between ridership demand and TOD indicators is explored in this study. The results of correlation analysis between transit ridership and other variables revealed that the high-rise building area is significantly related to the volume of transit ridership. Bus services have a stronger influence on transit ridership than railway stations and ferries (pier). Also, interchange stations and parkand-ride buildings are found to be the main variables that correlate directly with transit ridership numbers.

The results of principal component analysis (PCA) categorize the factors of TOD characteristics for the existing Bangkok metro stations into seven factors (groups). The first factor represents the area of population density with the connecting level of the street network and bus services. The second factor is based on land-use diversity. The third factor is the high-rise building area. The fourth factor represents the interchange stations, park-and-ride 


\begin{tabular}{|c|c|c|c|c|c|c|c|c|c|c|c|c|c|c|c|c|c|c|c|c|c|}
\hline Var & X11 & $\mathrm{X} 12$ & X13 & X21 & $\mathrm{X} 22$ & $\mathrm{X} 23$ & X24 & X25 & X31 & X32 & X33 & X34 & X35 & X36 & X37 & X38 & X39 & X310 & X311 & X312 & X313 \\
\hline $\mathrm{X} 11$ & 1.000 & & & & & & & & & & & & & & & & & & & & \\
\hline $\mathrm{X} 12$ & 0.540 & 1.000 & & & & & & & & & & & & & & & & & & & \\
\hline $\mathrm{X} 13$ & -0.137 & -0.050 & 1.000 & & & & & & & & & & & & & & & & & & \\
\hline $\mathrm{X} 21$ & 0.504 & -0.347 & -0.148 & 1.000 & & & & & & & & & & & & & & & & & \\
\hline X22 & 0.035 & -0.187 & -0.115 & 0.252 & 1.000 & & & & & & & & & & & & & & & & \\
\hline $\mathrm{X23}$ & -0.025 & 0.071 & -0.143 & -0.084 & 0.506 & 1.000 & & & & & & & & & & & & & & & \\
\hline X24 & -0.157 & -0.037 & -0.110 & $\mid 0.124$ & 0.884 & 0.579 & 1.000 & & & & & & & & & & & & & & \\
\hline $\mathrm{X} 25$ & -0.239 & 0.241 & -0.110 & \begin{tabular}{|l|}
-0.459 \\
\end{tabular} & 0.295 & 0.842 & 0.565 & \begin{tabular}{|l|}
1.000 \\
\end{tabular} & & & & & & & & & & & & & \\
\hline $\mathrm{X} 31$ & -0.348 & -0.002 & 0.135 & \begin{tabular}{|l|}
-0.437 \\
\end{tabular} & \begin{tabular}{|l|} 
\\
\end{tabular} & 0.112 & 0.056 & 0.356 & 1.000 & & & & & & & & & & & & \\
\hline $\mathrm{X32}$ & -0.277 & 0.103 & 0.156 & \begin{tabular}{|l|}
-0.440 \\
\end{tabular} & -0.227 & 0.059 & -0.049 & \begin{tabular}{|l|l|}
0.246 \\
\end{tabular} & 0.565 & 1.000 & & & & & & & & & & & \\
\hline $\mathrm{X} 33$ & -0.069 & 0.002 & -0.114 & \begin{tabular}{|l|}
-0.033 \\
\end{tabular} & \begin{tabular}{|l|}
0.334 \\
\end{tabular} & 0.266 & 0.338 & 0.168 & \begin{tabular}{|l|}
-0.060 \\
\end{tabular} & 0.046 & 1.000 & & & & & & & & & & \\
\hline $\mathrm{X34}$ & -0.140 & -0.028 & 0.042 & \begin{tabular}{|l|}
-0.124 \\
\end{tabular} & \begin{tabular}{|l|}
-0.031 \\
\end{tabular} & 0.064 & 0.013 & 0.110 & \begin{tabular}{|l|}
0.027 \\
\end{tabular} & 0.073 & -0.090 & 1.000 & & & & & & & & & \\
\hline $\mathrm{X35}$ & -0.157 & -0.190 & -0.067 & \begin{tabular}{|l|}
0.017 \\
\end{tabular} & 0.148 & -0.065 & \begin{tabular}{|l|}
0.267 \\
\end{tabular} & 0.051 & 0.167 & 0.035 & -0.800 & \begin{tabular}{|l|}
-0.057 \\
\end{tabular} & 1.000 & & & & & & & & \\
\hline X36 & 0.336 & 0.075 & -0.258 & 0.243 & 0.133 & 0.025 & -0.018 & \begin{tabular}{|l|}
-0.113 \\
\end{tabular} & \begin{tabular}{|l|} 
\\
\end{tabular} & -0.153 & -0.475 & 0.233 & -0.216 & 1.000 & & & & & & & \\
\hline $\mathrm{X} 37$ & -0.990 & 0.022 & -0.192 & \begin{tabular}{|l|}
-0.182 \\
\end{tabular} & -0.243 & 0.248 & 0.122 & 0.333 & \begin{tabular}{|l|} 
\\
\end{tabular} & -0.206 & -0.275 & \begin{tabular}{|l|}
0.214 \\
\end{tabular} & 0.205 & 0.158 & 1.000 & & & & & & \\
\hline $\mathrm{X38}$ & 0.229 & -0.146 & -0.206 & \begin{tabular}{|l|}
0.332 \\
\end{tabular} & 0.352 & 0.332 & 0.309 & 0.083 & \begin{tabular}{|l|}
-0.347 \\
\end{tabular} & \begin{tabular}{|l|}
-0.329 \\
\end{tabular} & -0.005 & \begin{tabular}{|l|}
-0.440 \\
\end{tabular} & 0.318 & 0.108 & 0.466 & 1.000 & & & & & \\
\hline X39 & 0.186 & 0.406 & 0.312 & -0.253 & \begin{tabular}{|l|}
-0.254 \\
\end{tabular} & $-0.164 \mid$ & -0.189 & 0.019 & 0.252 & 0.160 & -0.354 & -0.780 & -0.214 & -0.051 & -0.095 & -0.244 & 1.000 & & & & \\
\hline X310 & -0.213 & -0.106 & 0.007 & 0.091 & \begin{tabular}{|l|}
-0.141 \\
\end{tabular} & -0.051 & -0.067 & 0.022 & 0.241 & 0.026 & -0.201 & \begin{tabular}{|l|}
-0.101 \\
\end{tabular} & 0.339 & 0.100 & 0.308 & 0.122 & -0.200 & 1.000 & & & \\
\hline X311 & \begin{tabular}{|l|}
0.332 \\
\end{tabular} & -0.103 & 0.085 & 0.415 & 0.357 & -0.037 & 0.151 & -0.335 & \begin{tabular}{|l|} 
\\
\end{tabular} & -0.196 & 0.239 & 0.033 & -0.260 & 0.003 & 0.004 & 0.346 & \begin{tabular}{|l|}
-0.730 \\
\end{tabular} & \begin{tabular}{|l|}
-0.02 \\
\end{tabular} & 1.000 & & \\
\hline X312 & \begin{tabular}{|l|}
0.547 \\
\end{tabular} & 0.089 & -0.143 & \begin{tabular}{|l|l|}
0.463 \\
\end{tabular} & 0.384 & 0.072 & 0.183 & \begin{tabular}{|l|}
-0.248 \\
\end{tabular} & \begin{tabular}{|l|l|}
-0.484 \\
\end{tabular} & -0.425 & 0.107 & 0.006 & -0.200 & 0.161 & 0.131 & 0.578 & 0.099 & $|-0.20|$ & 0.84 & 1.000 & \\
\hline X313 & \begin{tabular}{|l|}
0.549 \\
\end{tabular} & 0.117 & -0.161 & \begin{tabular}{|l|l|}
0.549 \\
\end{tabular} & 0.208 & -0.077 & -0.229 & \begin{tabular}{|l|}
-0.331 \\
\end{tabular} & \begin{tabular}{|l|}
0.349 \\
\end{tabular} & \begin{tabular}{|l|}
-0.329 \\
\end{tabular} & 0.280 & \begin{tabular}{|l|}
-0.303 \\
\end{tabular} & \begin{tabular}{|l|}
-0.117 \\
\end{tabular} & 0.040 & -0.370 & \begin{tabular}{|l|}
0.121 \\
\end{tabular} & \begin{tabular}{|l|}
-0.167 \\
\end{tabular} & -0.27 & 0.59 & 0.59 & 1.000 \\
\hline
\end{tabular}

Fig. 8 Correlation matrix

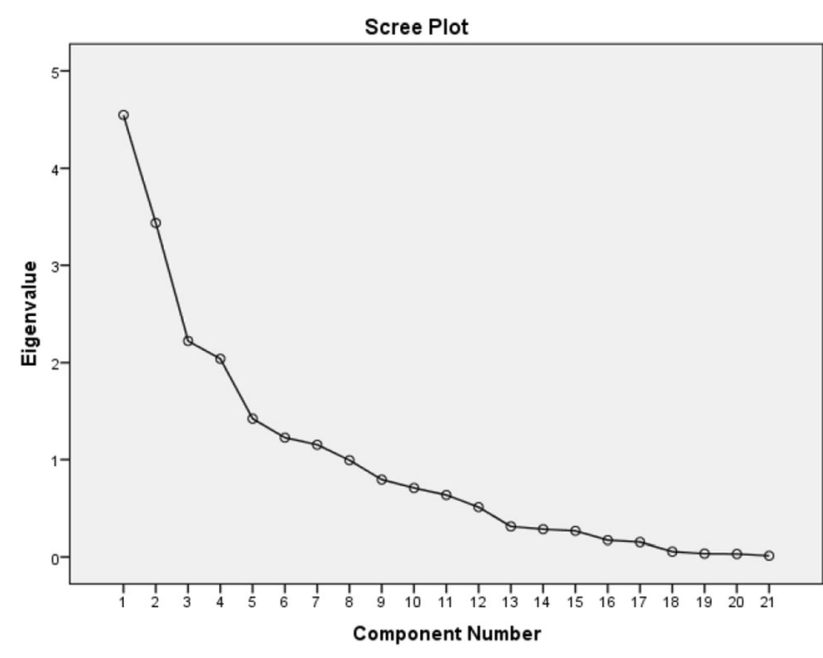

Fig. 9 Scree plot

buildings, and connection with bus services. The fifth factor is the residential area with ferry connections. The sixth factor is the accessibility of expressway and bus services. Finally, the seventh factor is the accessibility related to the distance to municipal public service facilities and landmarks and retail services.

Based on these findings, the critical issue for TOD, and the development that would influence more people to use public transportation in Bangkok, is improved public bus services. Most of the time, the public bus service competes with urban rail, both of which are convenient and have lower rider fees. However, the results of the correlation analysis clearly show that there is an excellent relationship between rail ridership demand and the number of bus services in the areas around the stations. This implies that, instead of traveling by public bus as a single trip, people in Bangkok tend to travel by bus and rail as a connecting mode from their origin to destination. Hence, considering the improvement of bus services as the feeder system will enhance overall public transport efficiency in Bangkok.

Additionally, based on the findings, the high-rise building area and area with high diversity or mixed use are key issues that land developers need to consider for improving demand for transit ridership.

Finally, these findings also imply that the stations that will always have high ridership demand are the interchange stations and the stations with a park-and-ride service. The TOD planner can give immediate attention to these stations in cases where development budgets are limited and a station development priority is needed.

\section{Stakeholder Analysis}

Based on the results and the discussion, it can be clearly seen that successful TOD in Bangkok requires cooperation from all transport authorities, especially the public bus authority, who can improve bus services in the area, and other public transport service authorities like metro system, who can work together to improve the overall accessibility of the public transport service in the area. In terms of land development, since changing land use is a key finding in 
Table 5 Correlations of 3D variables with the number of passengers

\begin{tabular}{llcc}
\hline Variables & Description & Correlation & $P$ value \\
\hline$X 11$ & Population density & -0.222 & 0.078 \\
$X 12$ & Population density (population/residential area) & -0.352 & 0.004 \\
$X 13$ & Population density (population/commercial area) & -0.100 & 0.429 \\
$X 21$ & Residential area & 0.160 & 0.208 \\
$X 22$ & Commercial, industrial, and mixed-use area & 0.217 & 0.085 \\
$X 23$ & Other activities area & -0.041 & 0.745 \\
$X 24$ & Proportion of commercial area relative to residential area & 0.193 & 0.127 \\
$X 25$ & Proportion of other activity area relative to residential area & -0.044 & 0.728 \\
$X 31$ & Distance to municipal public service facilities & -0.026 & 0.838 \\
$X 32$ & Access to landmarks and retail services & -0.132 & 0.299 \\
$X 33$ & Public transport accessibility & -0.148 & 0.243 \\
$X 34$ & Expressway accessibility & -0.048 & 0.706 \\
$X 35$ & Interchange stations & 0.496 & 0.000 \\
$X 36$ & Number of ferry services & 0.105 & 0.409 \\
$X 37$ & Number of bus lines & 0.31 & 0.013 \\
$X 38$ & Number of bus stops & 0.285 & 0.022 \\
$X 39$ & Number of railway stations & -0.271 & 0.030 \\
$X 310$ & Park-and-ride building & 0.623 & 0.000 \\
$X 311$ & Street network & 0.003 & 0.980 \\
$X 312$ & Street connectivity & 0.082 & 0.518 \\
$X 313$ & Network connectivity (cul-de-sac) & -0.104 & 0.414 \\
\hline & & &
\end{tabular}

Table 6 Pattern matrix

\begin{tabular}{|c|c|c|c|c|c|c|c|c|}
\hline \multirow[t]{2}{*}{ Variables } & \multirow[t]{2}{*}{ Description } & \multicolumn{7}{|c|}{ Component } \\
\hline & & 1 & 2 & 3 & 4 & 5 & 6 & 7 \\
\hline $\mathrm{X} 11$ & Population density & 0.453 & -0.011 & 0.616 & -0.138 & 0.311 & -0.253 & -0.101 \\
\hline $\mathrm{X} 12$ & Population density (residential area) & 0.084 & 0.033 & 0.948 & -0.176 & -0.025 & -0.080 & -0.049 \\
\hline $\mathrm{X} 13$ & Population density (commercial area) & 0.192 & -0.008 & -0.091 & -0.040 & 0.112 & 0.151 & 0.829 \\
\hline $\mathrm{X} 21$ & Residential area & 0.330 & -0.033 & -0.295 & 0.000 & 0.339 & -0.274 & -0.158 \\
\hline $\mathrm{X} 22$ & Commercial, industrial, and mixed-use area & 0.266 & 0.904 & -0.233 & -0.048 & 0.173 & -0.139 & 0.151 \\
\hline $\mathrm{X} 23$ & Other activities area & -0.116 & 0.818 & 0.180 & -0.124 & 0.038 & 0.108 & -0.182 \\
\hline $\mathrm{X} 24$ & Proportion of commercial area relative to residential area & 0.107 & 0.939 & -0.105 & 0.062 & 0.016 & -0.045 & 0.126 \\
\hline $\mathrm{X} 25$ & Proportion of other activity area relative to residential area & -0.393 & 0.726 & 0.295 & -0.024 & -0.043 & 0.123 & -0.142 \\
\hline $\mathrm{X} 31$ & Distance to municipal public service facilities & -0.448 & 0.219 & 0.067 & 0.330 & -0.011 & -0.225 & 0.405 \\
\hline $\mathrm{X} 32$ & Access to landmarks and retail services & -0.232 & 0.040 & 0.134 & 0.074 & -0.246 & 0.024 & 0.365 \\
\hline $\mathrm{X} 33$ & Public transport accessibility & 0.253 & 0.241 & -0.067 & -0.263 & -0.798 & -0.190 & -0.182 \\
\hline X34 & Expressway accessibility & 0.135 & 0.017 & -0.187 & -0.458 & 0.171 & 0.915 & 0.240 \\
\hline $\mathrm{X} 35$ & Interchange stations & -0.014 & 0.112 & -0.288 & 0.784 & 0.051 & -0.208 & -0.023 \\
\hline X36 & Number of ferry services & -0.139 & 0.212 & 0.026 & -0.046 & 0.959 & 0.142 & 0.069 \\
\hline X37 & Number of bus lines & 0.199 & -0.028 & 0.101 & 0.351 & 0.068 & 0.699 & -0.208 \\
\hline X38 & Number of bus stops & 0.564 & 0.194 & -0.037 & 0.380 & 0.047 & 0.243 & -0.267 \\
\hline X39 & Number of railway stations & 0.120 & -0.061 & 0.583 & 0.027 & 0.186 & -0.062 & 0.616 \\
\hline X310 & Park-and-ride building & 0.062 & -0.170 & -0.045 & 0.843 & 0.026 & -0.102 & 0.041 \\
\hline X311 & Street network & 1.145 & 0.004 & -0.008 & 0.054 & -0.285 & 0.142 & 0.321 \\
\hline X312 & Street connectivity & 1.097 & 0.068 & 0.177 & 0.082 & -0.065 & 0.156 & 0.095 \\
\hline X313 & Network connectivity (cul-de-sac) & 0.593 & -0.018 & 0.171 & -0.022 & -0.152 & -0.523 & -0.098 \\
\hline
\end{tabular}

The bold numbering indicates the strong relationship of the specific variable in influencing the paticular factor 
the increased demand for transit ridership, the land authority is also a key stakeholder. Patterns and effects of land-use changes based on transport accessibility improvement in the area will need to be further considered in detail. Explicit directions for land development in the area are also needed for sustainable development in the future.

Open Access This article is licensed under a Creative Commons Attribution 4.0 International License, which permits use, sharing, adaptation, distribution and reproduction in any medium or format, as long as you give appropriate credit to the original author(s) and the source, provide a link to the Creative Commons licence, and indicate if changes were made. The images or other third party material in this article are included in the article's Creative Commons licence, unless indicated otherwise in a credit line to the material. If material is not included in the article's Creative Commons licence and your intended use is not permitted by statutory regulation or exceeds the permitted use, you will need to obtain permission directly from the copyright holder. To view a copy of this licence, visit http://creativecommons. org/licenses/by/4.0/.

\section{References}

1. (2018) 'Robust' economic growth in Asia-Pacific last year and 'promising' prospects ahead-UN report. In: UN News. https:// news.un.org/en/story/2018/05/1009102. Accessed 19 Jan 2019

2. Oxford Economics (2016) Assessing the global transport infrastructure market: outlook to 2025. In: Marketmaker Group. https:// marketmaker-group.com/pwc-report-assessing-the-global-transportinfrastructure-market-outlook-to-2025/. Accessed 13 Dec 2018

3. Liang X, de Almeida Correia GH, van Arem B (2016) Optimizing the service area and trip selection of an electric automated taxi system used for the last mile of train trips. Transp Res Part E Logist Transp Rev 93:115-129. https://doi.org/10.1016/j.tre. 2016.05.006

4. Scheltes A, de Almeida Correia GH (2017) Exploring the use of automated vehicles as last mile connection of train trips through an agent-based simulation model: an application to Delft, Netherlands. Int J Transp Sci Technol 6:28-41. https://doi.org/10. 1016/j.ijtst.2017.05.004

5. Yap MD, Correia G, van Arem B (2016) Preferences of travellers for using automated vehicles as last mile public transport of multimodal train trips. Transp Res Part A Policy Pract 94:1-16. https://doi.org/10.1016/j.tra.2016.09.003

6. Liu Z, Jia X, Cheng W (2012) Solving the last mile problem: ensure the success of public bicycle system in Beijing. Procedia Soc Behav Sci 43:73-78. https://doi.org/10.1016/j.sbspro.2012. 04.079

7. Office of Transport and Traffic Policy and Planning (2019) คมนาคมสร้างเมือง เมืองสร้างสุบ สุบสร้างได้. http://www.thai landtod.com/project.html. Accessed 20 Jun 2019

8. Curtis C (2012) Delivering the " $D$ " in transit-oriented development: examining the town planning challenge. J Transp Land Use 5:83-99

9. Calthorpe P (1993) The Next American Metropolis. http://www. papress.com/html/product.details.dna?isbn $=9781878271686$. Accessed 11 Dec 2018

10. Belzer D, Aulter G (2002) Transit oriented development: moving from rhetoric to reality-Reconnecting America. http://www. reconnectingamerica.org/resource-center/browse-research/2002/ transit-oriented-development-moving-from-rhetoric-to-reality/. Accessed 12 Dec 2018

11. Cervero R, Day J (2008) Suburbanization and transit-oriented development in China. Transp Policy 15:315-323. https://doi.org/ 10.1016/j.tranpol.2008.12.011

12. Curtis C (2009) Transit oriented development-making it happen -Reconnecting America. http://www.reconnectingamerica.org/ resource-center/books-and-reports/2009/transit-oriented-develop ment-making-it-happen/SearchForm/?Search=Carey+Curtis. Accessed 12 Dec 2018

13. Zhou J, Yang Y, Gu P et al (2019) Can TODness improve (expected) performances of TODs? An exploration facilitated by non-traditional data. Transp Res Part D Transp Environ 74:2847. https://doi.org/10.1016/j.trd.2019.07.008

14. Kamruzzaman Md, Shatu FM, Hine J, Turrell G (2015) Commuting mode choice in transit oriented development: disentangling the effects of competitive neighbourhoods, travel attitudes, and self-selection. Transp Policy 42:187-196. https:// doi.org/10.1016/j.tranpol.2015.06.003

15. Chava J, Newman P, Tiwari R (2018) Gentrification of station areas and its impact on transit ridership. Case Stud Transp Policy 6:1-10. https://doi.org/10.1016/j.cstp.2018.01.007

16. Ewing R, Tian G, Park K et al (2019) Comparative case studies: trip and parking generation at Orenco Station TOD, Portland Region and Station Park TAD, Salt Lake City Region. Cities 87:48-59. https://doi.org/10.1016/j.cities.2018.12.020

17. Reece DC, Marinov M (2015) Modelling the implementation of a baggage transport system in Newcastle upon Tyne for passengers using mixed-mode travel. Transp Probl 10(4):149-155

18. Daly H, Ramea K, Chiodi A et al (2012) Modal choice in a TIMES model. IEA-ETSAP

19. Luan X, Cheng L, Song Y, Zhao J (2002) Better understanding the choice of travel mode by urban residents: new insights from the catchment areas of rail transit stations. Sustain Cities Soc 53:101968. https://doi.org/10.1016/j.scs.2019.101968

20. Chakrabarti S (2017) How can public transit get people out of their cars? An analysis of transit mode choice for commute trips in Los Angeles. Transp Policy 54:80-89. https://doi.org/10.1016/ j.tranpol.2016.11.005

21. Yu L, Xie B, Chan EHW (2019) Exploring impacts of the built environment on transit travel: distance, time and mode choice, for urban villages in Shenzhen, China. Transp Res Part E Logist Transp Rev 132:57-71. https://doi.org/10.1016/j.tre.2019.11.004

22. Litman T (2008) Sustainable transportation indicators: a recommended program to define a standard set of indicators for sustainable transportation planning

23. Sulistyaningrum S, Sumabrata J (2018) Transit Oriented Development (TOD) index at the current transit nodes in Depok City, Indonesia. IOP Conf Ser Earth Environ Sci 126:012217. https:// doi.org/10.1088/1755-1315/126/1/012217

24. Haghshenas H, Vaziri M (2012) Urban sustainable transportation indicators for global comparison. Ecol Ind 15:115-121. https:// doi.org/10.1016/j.ecolind.2011.09.010

25. Zhang Y, Guindon B (2006) Using satellite remote sensing to survey transport-related urban sustainability: part 1: methodologies for indicator quantification. Int $\mathbf{J}$ Appl Earth Obs Geoinf 8:149-164. https://doi.org/10.1016/j.jag.2005.08.005

26. Loo BPY, Chen C, Chan ETH (2010) Rail-based transit-oriented development: lessons from New York City and Hong Kong. Landsc Urban Plan 97:202-212. https://doi.org/10.1016/j.land urbplan.2010.06.002

27. Sung H, Oh J-T (2011) Transit-oriented development in a highdensity city: identifying its association with transit ridership in Seoul, Korea. Cities 28:70-82. https://doi.org/10.1016/j.cities. 2010.09.004 
28. Cervero R, Kockelman K (1997) Travel demand and the 3Ds: density, diversity, and design. Transp Res Part D Transp Environ 2:199-219. https://doi.org/10.1016/S1361-9209(97)00009-6

29. Lukman A (2014) Development and implementation of a transit oriented development (TOD) index around the current transit nodes. Urban Plan Manag 74

30. Singh YJ, Fard P, Zuidgeest M et al (2014) Measuring transit oriented development: a spatial multi criteria assessment approach for the City Region Arnhem and Nijmegen. J Transp Geogr 35:130143. https://doi.org/10.1016/j.jtrangeo.2014.01.014

31. Kamruzzaman Md, Baker D, Washington S, Turrell G (2014) Advance transit oriented development typology: case study in Brisbane, Australia. J Transp Geogr 34:54-70. https://doi.org/10. 1016/j.jtrangeo.2013.11.002

32. Vale DS (2015) Transit-oriented development, integration of land use and transport, and pedestrian accessibility: combining nodeplace model with pedestrian shed ratio to evaluate and classify station areas in Lisbon. J Transp Geogr 45:70-80. https://doi.org/ 10.1016/j.jtrangeo.2015.04.009

33. Lyu G, Bertolini L, Pfeffer K (2016) Developing a TOD typology for Beijing metro station areas. J Transp Geogr 55:40-50. https:// doi.org/10.1016/j.jtrangeo.2016.07.002

34. Singh YJ, Lukman A, Flacke J et al (2017) Measuring TOD around transit nodes- towards TOD policy. Transp Policy 56:96111. https://doi.org/10.1016/j.tranpol.2017.03.013
35. Gu P, He D, Chen Y et al (2018) Transit-oriented development and air quality in Chinese cities: a city-level examination. Transp Res Part D Transp Environ 68:10-25. https://doi.org/10.1016/j. trd.2018.03.009

36. University of Southamton (2019) WorldPop: population. https:// www.worldpop.org/project/categories?id=3. Accessed 22 Jun 2019

37. Höhn J, Lehtonen E, Rasi S, Rintala J (2014) A Geographical Information System (GIS) based methodology for determination of potential biomasses and sites for biogas plants in southern Finland. Appl Energy 113:1-10. https://doi.org/10.1016/j.ape nergy.2013.07.005

38. Laasasenaho K, Lensu A, Lauhanen R, Rintala J (2019) GIS-data related route optimization, hierarchical clustering, location optimization, and kernel density methods are useful for promoting distributed bioenergy plant planning in rural areas. Sustain Energy Technol Assessm 32:47-57. https://doi.org/10.1016/j. seta.2019.01.006

39. Cohen J (1988) Statistical power analysis for the behavioral sciences, 2nd edn. Routledge, Hillsdale

40. Sharma S (1996) Applied multivariate techniques. Wiley, New York 